\title{
急拡大を伴う鉛直円管内を上昇する気泡流のボイド率分布*
}

\author{
近藤 宏 ${ }^{* 1}$, 吉田憲司*2, 松 本 忠 義*2 \\ 大川富 雄*2, 片 岡勲*2
}

\section{Void Fraction Distribution of Upward Bubbly Flow in a Vertical Pipe with Sudden Expansion}

\author{
Koichi KONDO*3, Kenji YOSHIDA, Tadayoshi MATSUMOTO, \\ Tomio OKAWA and Isao KATAOKA \\ ${ }^{* 3}$ Department of Marine Engineering, Marine Technical College, \\ 12-24 Nishikura-cho, Ashiya-shi, Hyogo, 659-0026 Japan
}

\begin{abstract}
Experimental study was made on the multi-dimensional behavior of upward gas-liquid twophase flow through a vertical pipe with an axisymmetric sudden expansion. In this study, the measurement on the void fraction distribution was carried out for the sudden expansion channel. The void fraction distributions below and above the sudden expansion point were measured at the different axial and radial positions using a point-electrode resistivity probe for various gas and liquid flow conditions. The results of measured void fraction distributions showed that how the twophase flow develops along the direction of the downstream of the sudden expansion. Furthermore, the development of the void fraction distribution also revealed quite complicated behaviors depending upon flow rates of gas and liquid phases and bubble size. Based on the measured void fraction distribution in the sudden expansion, cross $^{-}$sectional averaged void fraction and phase distribution parameter were evaluated at the different tube cross sections in the sudden expansion. As a result, it revealed that the void fraction along the flow direction in the sudden expansion might be predicted by using the appropriate distribution parameter representing the void fraction distributions in the sudden expansion.
\end{abstract}

Key Words : Bubbly Flow, Pipe Flow, Sudden Expansion, Void Fraction, Distribution Parameter

\section{1. 緒言}

気液二相流動を詳細に解明することは，様々な沸騰 伝熱機器における伝熱・流動特性を理解し, またその 性能評価や安全解析, 設計のための合理的なモデリン グやシミュレーションを行う際に必要不可欠であり, 極めて重要である.

従来の気液二相流解析では, 主流方向の一次元解析 に基づくものが多く行われてきた(1)(4). しかしながら, 一般に流路内における気液二相流では流速やボイド率 等の諸值は多次元構造を有していることが明らかにさ れている(5)(9)。また，実際の沸騰伝熱機器では曲がり 管や複雑な断面を有する流路, あるいは断面積が変化 する流路等の多次元形状をもつ流路が数多く存在する. このことから,より正確かつ一般的な二相流動を予測

* 原稿受付 2004 年 6 月 23 日.

*1 正員, (独) 海技大学校 ( $\mathbf{W} 659-0026$ 声屋市西藏町 12-24).

*2 正員, 大阪大学大学院工学研究科 (- 565-0871 吹田市山田 丘 $2-1$ ).

E-mail : kondou@mail.mtc.ac.jp
するためには多次元流路における気液二相流の多次元 的流動挙動や構造を詳細に解明することが必要である. 筆者らは，実験室レベルの比較的簡単な体系下での多 次元的流路における二相流動・構造の解明を目的とし て多次元現象の典型的な形態である急挔大を伴う鉿直 円管内を上昇する非加熱空気-水系気液二相流を対象 に研究を行っている.この急抎大流路は, はく離, 再 付着, 循環などの多次元的な要素を持つ流れ場であり, 原子炬内における燃料集合体から上部プレナムに至る 沸騰二相流路がその代表的な実用例である.これまで に急拡大流路において引き起こされる特徵的な二相流 動現象や急拡大部が及ぼす流動様式への影響などを実 験的に明らかにしてきた(10).

気液二相流の微細構造や多次元構造を決定する重要 な特性としてボイド率分布が挙げられる.このボイド 率分布に影響を及ぼす因子として，気相ならびに液相 流速，管路形状，流れの過渡特性，ボイド発生条件あ るいは混合方法, 気泡サイズなどが挙げられる。これ 
までにも管軸方向および管断面方向におけるボイド率 分布に関して実験的あるいは解析的な研究がいくつか なされ，ボイド率分布予測方法の確立に対しての実績 が挙げられている. しかしながら，鉛直単円管内を上 昇する気泡流のボイド率分布に関する知見は数多く見 られるが, 多次元的な流路に関してはいくつかの報告 がなされている程度である(11)(14). したがって,この ような多次元的なボイド率分布デー夕を明らかにする ことは, 気泡挙動メカニズムの解明のみならず, 今後 の多次元二相流解析へ適用できるとともに, 数值解析 のための有用な検証データとなり得ると考えられる.

本報では, 多次元流路における気液二相流の多次元 的な挙動を明らかにすることを目的に，急拡大を伴う 鈶直円管内を上昇する非加熱空気-水系気泡流を対象 として点電極式ボイドプローブを用いてボイド率分布 の測定を実施した．急拡大流路におけるボイド率分布 を様々な気液流束条件や気泡サイズにわたって詳細に 明らかにし気液二相流の多次元挙動解析に関する実験 データを提示するとともに，急拡大部上流域から下流 域に至る管断面平均ボイド率分布の変化や一次元モデ ルの予測に対する可能性の検討を行った.

\section{主な 記 号}

$\begin{array}{lll}C_{0} & \text { :分布定数 } & {[-]} \\ D & \text { :管径 } & {[\mathrm{mm}]} \\ d_{\mathrm{b}} & \text { :気泡径 } & {[\mathrm{mm}]} \\ j & \text { :体積流束 } & {[\mathrm{m} / \mathrm{s}]} \\ R & \text { :管半径 } & {[\mathrm{mm}]} \\ r & \text { :管中心からの位置 } & {[\mathrm{mm}]} \\ V_{\mathrm{Gj}} & : \text { :ドフト速度 } & {[\mathrm{m} / \mathrm{s}]} \\ Z & \text { :管軸方向位置 } & {[\mathrm{mm}]} \\ \alpha & \text { :ボイド率 } & {[-]} \\ \langle\alpha\rangle & \text { :管断面平均ボイド率 } & {[-]} \\ & \left(=\frac{1}{\pi R^{2}} \int_{0}^{R} 2 \pi r \cdot \alpha \mathrm{d} r\right) & \end{array}$

添字

G : 気相

L : 液相

$20: 20 \mathrm{~mm}$ 管

$50 \quad: 50 \mathrm{~mm}$ 管

\section{2. 実験装置と実験方法}

実験対象は, 内径 $20.0 \mathrm{~mm}$ の上流側の円管（以下, $20 \mathrm{~mm}$ 管という）と内径 $50.0 \mathrm{~mm}$ の下流側の円管 （以下， $50 \mathrm{~mm}$ 管という）を鈶直同軸に結合した急

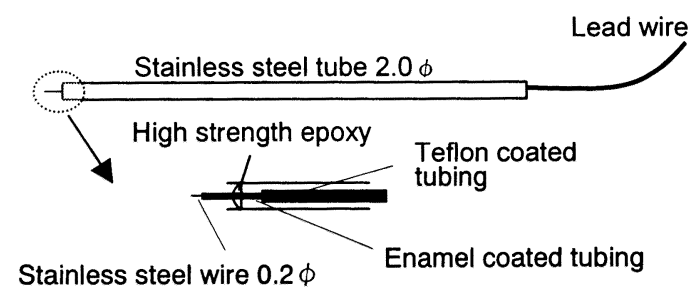

Fig. 1 A point-electrode resistivity probe

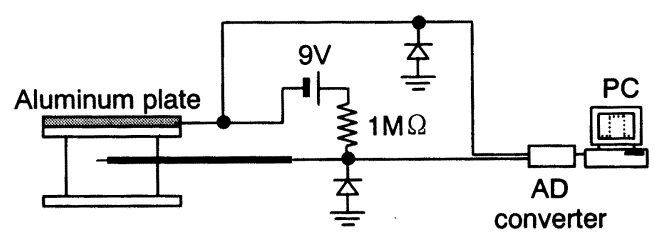

Fig. 2 Data processing system

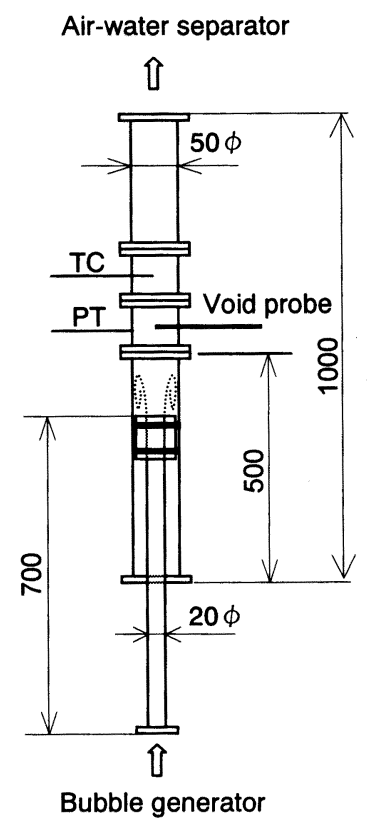

Fig. 3 Measuring section

拡大流路内 ${ }^{(10)}$ を鈶直上昇する大気圧条件下での空気水系の気泡流である.

この急抎大流路におけるボイド率分布を点電極式プ ローブにより測定する. 図 1 は本実験で使用した点電 極式プローブの概略図であり, 急拡大部における気泡 の多次元挙動を考慮しボイド率測定にはストレート形, すなわち I 形プローブを使用した. プローブ先端の細 線部には直径 $0.2 \mathrm{~mm}$ のステンレス製ワイヤを使用し, 
先端部を除いて外径 $0.36 \mathrm{~mm}$ のテフロンチューブで 被覆し外部との絶縁を施した．細線の先端部は，先端 面以外の部分で絶縁性を得るために, 絶縁エナメル樹 脂をコーティングした上で, さらに $200^{\circ} \mathrm{C}$ の恒温槽内 で焼結させた．この細線を直径 $2.0 \mathrm{~mm}$ のステンレス 製さや管に挿入しエポキシ系接着剤で固定している. このプローブにより検出されたボイド信号は図 2 に示 す信号処理回路と $\mathrm{AD}$ コンバータを用いてパーソナ ルコンピュータで直接処理しボイド率を求める. また, 急拡大部におけるボイド率の測定では図 3 の供試管を 用いる. ボイドプローブはトラバース装置の装着によ り，マイクロメータを用いてプローブ先端を管半径方 向の任意の位置に移動, 固定することが可能である. また, 急拡大部はプローブとの距離を $0 \sim 500 \mathrm{~mm}$ の 範囲で移動させることができる構造となっている. 本 実験に際して, このボイド信号の $\mathrm{S} / \mathrm{N}$ 比を向上させ るため液相の比抵抗を低レベルで一定となるよう塩化 カリウムを微量投入した. 実験中この比抵抗を電気伝 導度計により監視することで一定条件の下で実験が行 われるよう配慮した.

ボイド率測定実験にあたり, 管内圧の変化に起因す る気相の下流方向における体積膨張を考慮する必要が ある. 本実験ではボイドプローブを挿入している正面 位置から半導体圧力計（PT）により液相の静圧を, この上部において熱電対（TC）により液相の温度を 測定することでボイド率測定部に対する気相流量の補 正を行った.

一般に, 点電極式プローブによるボイド率測定は上 流形，すなわち L 形プローブが採用されていること が多いので, I 形プローブの妥当性を検討するために 予備実験として $50 \mathrm{~mm}$ 管において I 形プローブと L 形 プローブを用いたボイド率の測定を行った．図4はをそ の結果の一例を示す. 図の横軸は管中心軸からの無次 元位置，縦軸はボイド率測定の結果である. 図中の Z $=500 \mathrm{~mm}$ は, 急抗大部から $500 \mathrm{~mm}$ 下流位置を示す.

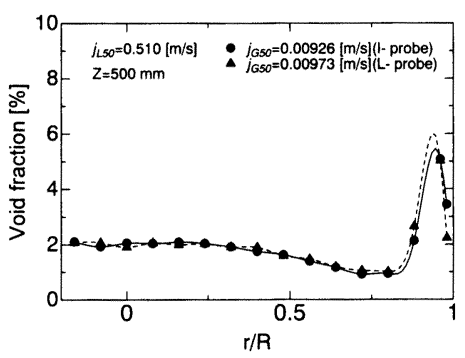

Fig. 4 Comparison of measuring data between I-probe and L-probe
I 形プローブの結果は丸印（），L 形プローブは三 角印（山）で示している．これより，両プローブを使 用して測定したボイド率測定結果に大きな違いが見ら れない，異なる条件においても同様に，I 形プローブ と L 形プローブによる測定結果に大きな違いは見ら れなかった. よって, 後述のボイド率分布の考察につ いてはこの結果を基に議論を進める.

実験条件として，流動観察実験で得られた急挔大を 伴う円管流路に対する流動様式判定線図 ${ }^{(10)}$ に基づき, 急拡大部上流側の $20 \mathrm{~mm}$ 管における液相体積流束 $j_{200}$ を 0.265 から $5.31 \mathrm{~m} / \mathrm{s}$, 気相の体積流束 $j_{\mathrm{G} 20}$ を約 0.05
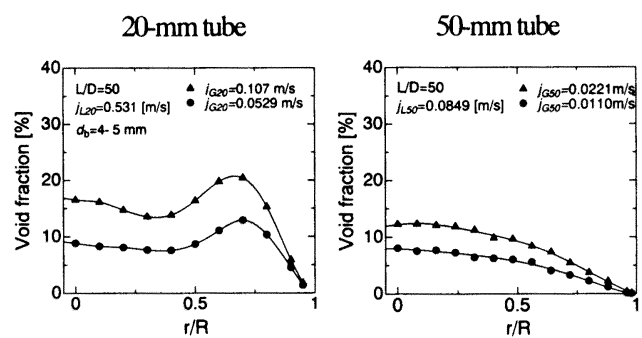

(a) $j_{L 20}=0.531 \mathrm{~m} / \mathrm{s}, j_{L 50}=0.0849 \mathrm{~m} / \mathrm{s}, d_{b 20}=4-5 \mathrm{~mm}$
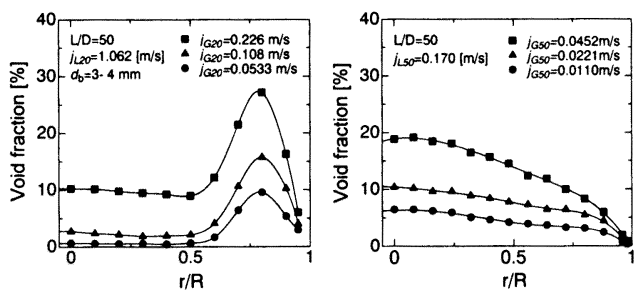

(b) $j_{L 20}=1.06 \mathrm{~m} / \mathrm{s}, j_{L 50}=0.170 \mathrm{~m} / \mathrm{s}, d_{b 20}=3-4 \mathrm{~mm}$
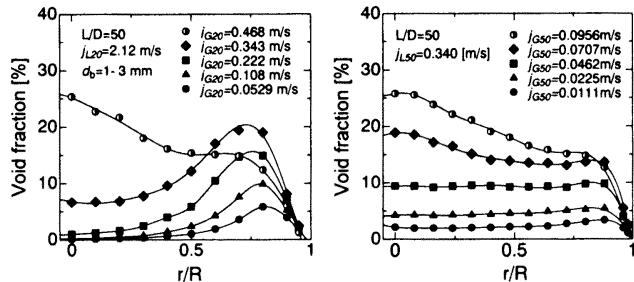

(c) $j_{L 20}=2.12 \mathrm{~m} / \mathrm{s}, j_{L S 0}=0.34 \mathrm{~m} / \mathrm{s}, d_{b 20}=1-3 \mathrm{~mm}$
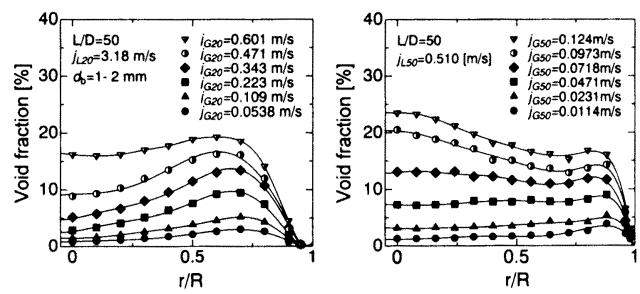

(d) $j_{L 20}=3.19 \mathrm{~m} / \mathrm{s}, j_{L 50}=0.510 \mathrm{~m} / \mathrm{s}, d_{b 20}=1-2 \mathrm{~mm}$

Fig. 5 Void fraction distribution of fullydeveloped region 
から $0.6 \mathrm{~m} / \mathrm{s}$ の範囲で変化させた気泡流領域を対象と した.

\section{3. 実験結果と考察}

\section{1 急拡大部上流領域および下流領域におけるボ} イド率分布＼cjkstart急拡大部におけるボイド率の測定に先 立ち，まずは $20 \mathrm{~mm}$ 管および $50 \mathrm{~mm}$ 管それぞれの下 流領域において管断面ボイド率分布の測定を行った.

測定位置は, 気泡発生器あるいは急拡大部から $1.0 \mathrm{~m}$ および $2.5 \mathrm{~m}$ 下流の位置とした.これは，いずれも管 直径 D の 50 倍に相当し, 二相流が十分発達した位置 である（図中には $\mathrm{L} / \mathrm{D}=50$ で表す）。図 5 は $20 \mathrm{~mm}$ 管（左側）および $50 \mathrm{~mm}$ 管（右側）それぞれの結果 を示す．従来の知見で得られている単円管に関する鈶 直上昇分散気泡流の研究では, 気液流束や気泡径が变 化することで壁面近傍にピークを持つ鞍形分布や，管 中心にピークを持つべき乗則分布などがボイド率分布 として現れることが示されている( けるボイド率測定結果では, 低液流束条件では壁面に 気泡が集中する鞍型分布が現れ，高液流束条件になる につれて壁面のボイドピークが緩やかになり気泡が管
中心にも集まることで管断面に渡って気泡が存在する 分布へと变化する. 一方, $50 \mathrm{~mm}$ 管における測定結 果は, $20 \mathrm{~mm}$ 管に比べて低い液流束となることから低 液流束条件では管中心部に気泡が集まるべき乗則分布 となり，高液流束条件では壁面付近に気泡が集まる傾 向を示すボイド率分布となった.この $20 \mathrm{~mm}$ 管およ び $50 \mathrm{~mm}$ 管の十分発達した領域における気泡流のボ イド率測定結果は，従来の傾向と同様であることが確 認された(5)

3.2 急拡大流路におけるボイド率分布急拡大 部における管断面ボイド率分布について管軸方向の測 定位置を任意に変化させ，ボイド率の二次元分布を詳 細に測定した. 図 6は一定の気相流束条件 $\left(j_{620}=0.05\right.$ $\mathrm{m} / \mathrm{s}$ 程度）の下で液相流束を変化させた場合の急拡大 流路内でのボイド率分布測定結果であり，急拡大部以 降の代表的な管断面位置でそれぞれ表している．横軸 は管中心軸からの無次元位置を示し，縦軸は管軸方向 位置ならびにボイド率を示す. $\mathrm{Z}=0 \mathrm{~mm}$ は急拡大部 に相当する. $Z=1 \mathrm{~mm}$ における測定結果は, $20 \mathrm{~mm}$ 管において測定されたボイド率分布と同様の分布であ ることが図 5 より確認できる. また，この $20 \mathrm{~mm}$ 管
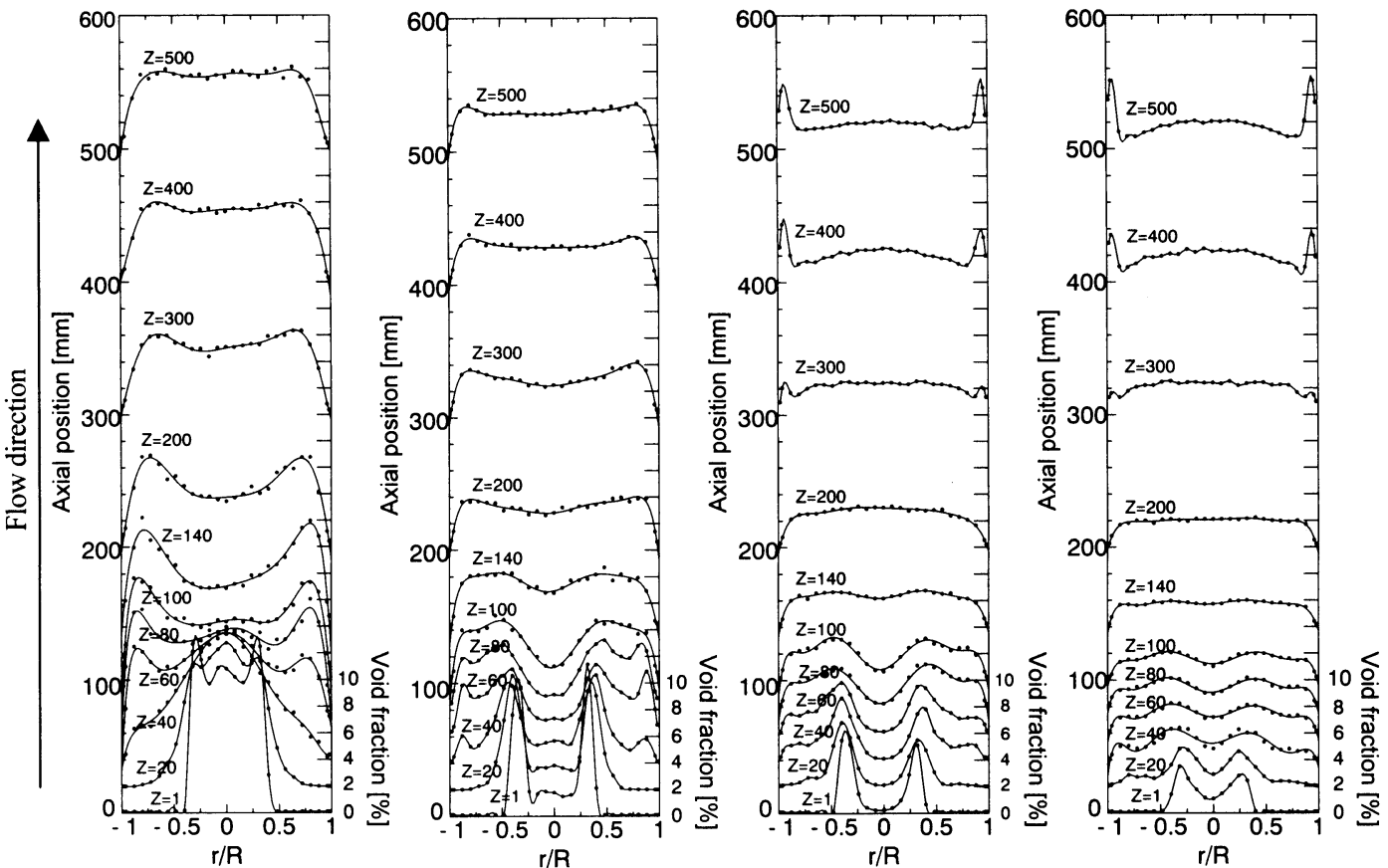

$$
\text { (a) } \begin{aligned}
j_{\mathrm{L} 20} & =0.531 \mathrm{~m} / \mathrm{s} \\
j_{\mathrm{G} 20} & =0.0529 \mathrm{~m} / \mathrm{s} \\
d_{\mathrm{b} 20} & =4-5 \mathrm{~mm}
\end{aligned}
$$
(b) $j_{\mathrm{L} 20}=1.06 \mathrm{~m} / \mathrm{s}$ $j_{\mathrm{G} 20}=0.0533 \mathrm{~m} / \mathrm{s}$ $d_{\mathrm{b} 20}=3-4 \mathrm{~mm}$
(d) $j_{\mathrm{L} 20}=3.19 \mathrm{~m} / \mathrm{s}$ $j_{\mathrm{G} 20}=0.0538 \mathrm{~m} / \mathrm{s}$ $d_{\mathrm{b} 20}=1-2 \mathrm{~mm}$

Fig. 6 Void fraction distribution in the sudden expansion under the low gas flux condition 
におけるボイド率分布がここでは境界条件となり、こ れらが急挔大部下流にいくにしたがい半径方向へ挔散 しながら発達する様子が測定されている.これより, 急拡大部から $200 \mathrm{~mm}$ 付近の下流位置においてボイド 率分布がほぼ均一な分布を呈し, その後 $50 \mathrm{~mm}$ 管の 発達域へと移行していることがわかる.

低液流束条件では（図 6 (a) および (b)），前述のよ うに急拡大部から $40 \mathrm{~mm}$ 位置以降の発達中の領域の 壁面付近において高いボイド率の值が測定されている ことがわかる.これは気泡がこの付近で形成される循 環流領域で停滞する現象によるものである(10). 図 7 (a) にこの流れの様子を示す. 急拡大部では液相せん断層 と管壁との間に逆流領域を形成する. 気泡は低液流束 条件では急拡大部から管断面全体に分布するが, 壁面 付近の気泡には (1)，逆流領域の影響で上流方向一 の力が働く、しかしながら, 比較的大きなサイズの気 泡であることによる浮力とのバランスで気泡は管壁面 付近に停滞するようになり (2)），その後下流方向へ 放出されるようになる (3)）。この結果, 低流束条 件では前述のようなボイド率分布が測定されたもので ある.

一方, 高液流束条件の結果では（図 6 (c) および (d) ）, 急拡大部発達領域において気泡は半径方向へ 拡散する挙動を示すと同時に循環流の影響により急拡 大部付近まで逆流することが確認された（図 7 (b) 参 照）。さらにこの流束条件では, 急拡大部で形成され る液相のせん断層により気泡の変形, 分裂現象 ${ }^{(10)}$ が引 き起こされるため気泡は必ずしも管壁面方向には移動 せず，壁面付近で高いボイド率を示す傾向はないこと がわかった。

なお，本急拡大流路における気泡流の範囲で気液流

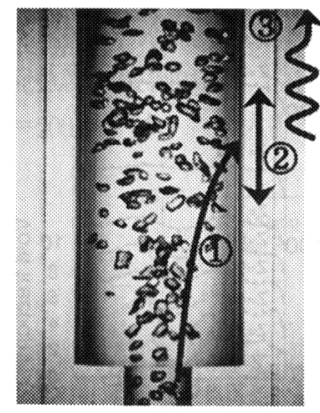

$j_{\mathrm{L} 20}=0.531 \mathrm{~m} / \mathrm{s}$ $j_{\mathrm{G} 20}=0.0537 \mathrm{~m} / \mathrm{s}$ $d_{\mathrm{b}}=4-5 \mathrm{~mm}$

(a)

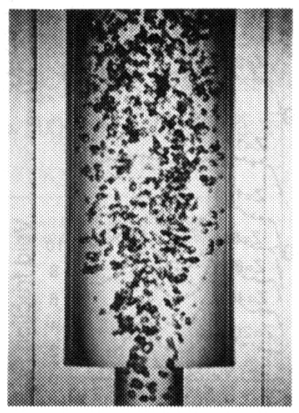

$j_{\mathrm{L} 20}=2.12 \mathrm{~m} / \mathrm{s}$ $j_{\mathrm{G} 20}=0.0550 \mathrm{~m} / \mathrm{s}$ $d_{\mathrm{b}}=1-3 \mathrm{~mm}$

(b)
Fig. 7 Bubble behaviors in the sudden expansion
量を様々に変化させた場合のボイド率分布測定デー夕 を付図 1 として添付する. 基本的には図 5 と同様の傾 向を示しているが, 詳細は付図 1を参照されたい.

\section{3 管断面平均ボイド率分布急抎大部におけ} る多次元的なボイド率分布の結果を基に，ここでは急 抎大部における管断面平均ボイド率を算出する. 図 8 にその結果を示す，縦軸は管断面平均ボイド率であり， 横軸は管軸方向位置で $\mathrm{Z}=0$ が急挔大部に相当し, 左 側が $20 \mathrm{~mm}$ 管, 右側が $50 \mathrm{~mm}$ 管の結果をそれぞれ示 している.

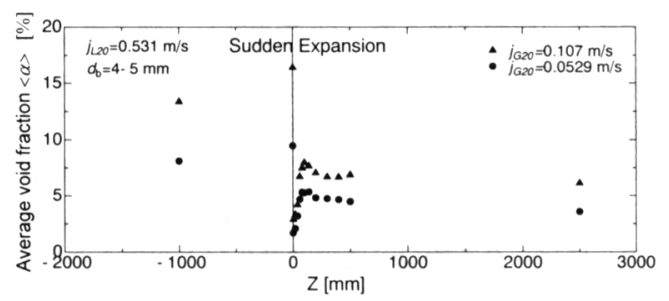

(a) $j_{L 20}=0.531 \mathrm{~m} / \mathrm{s}, d_{b 20}=4-5 \mathrm{~mm}$

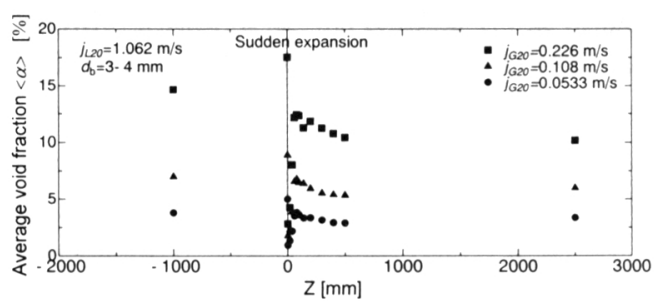

(b) $j_{L 20}=1.062 \mathrm{~m} / \mathrm{s}, d_{b 20}=3-4 \mathrm{~mm}$

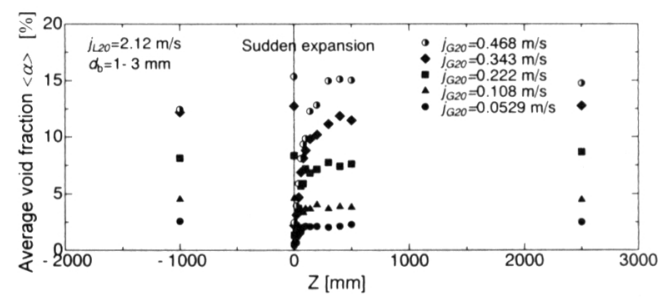

(c) $j_{L 20}=2.12 \mathrm{~m} / \mathrm{s}, d_{b 20}=1-3 \mathrm{~mm}$

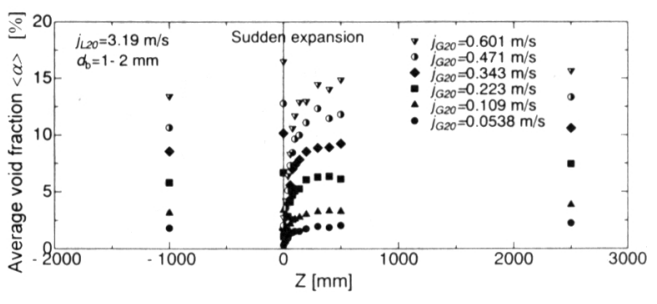

(d) $j_{L 20}=3.19 \mathrm{~m} / \mathrm{s}, d_{b 20}=1-2 \mathrm{~mm}$

Fig. 8 Cross-sectional averaged void fraction distribution in the sudden expansion. 


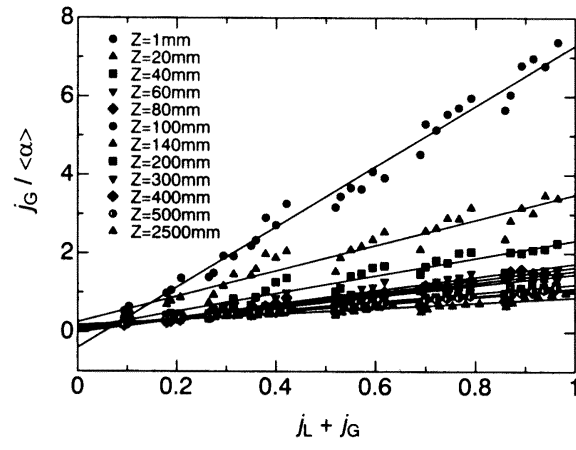

Fig. 9 Relationship between $j_{\mathrm{L}}+j_{\mathrm{G}}$ and $j_{\mathrm{G}} / \bar{\alpha}$

図 8 より，すべての流束条件に対して $20 \mathrm{~mm}$ 管か ら $50 \mathrm{~mm}$ 管に流路断面積が急抎大することから管断 面平均ボイド率は急激に隇少する. 高液流束条件で は（図 8 (c) および (d)），管断面平均ボイド率は急拡 大部から下流領域へ移行するにつれて単調に増加する 傾向を示している.

一方，低流束条件では（図 8 (a) および (b)），急拡 大部で減少した管断面平均ボイド率が急挔大流路の $100 \mathrm{~mm}$ 下流位置まで急激に増加しているものの, そ の後减少しながら一定值に達する傾向を示した. この ことは前述の急搪大部付近で見られる壁面付近に気泡 が停滞する挙動およびボイド率分布によって説明する ことが可能であり, 何らかの多次元的なモデリングが 必要であろうことを示唆するものである.

3.4 急拡大部における分布定数 気液の体積流 束とボイド率とを評価する一次元ドリフトフラックス 相関式は次式で与えられる(2).

$$
\frac{j_{G}}{\langle\alpha\rangle}=C_{0}\left(j_{L}+j_{G}\right)+V_{G j}
$$

式(1)において, 気相体積流束 $j_{\mathrm{G}}$ および液相体積流束 $j_{\mathrm{L}}$ 分布定数 $C_{0}$, ドリフト速度 $V_{\mathrm{Gj}}$ が適切に評価され れば管内の軸方向のボイド率分布を予測することが可 能と考えられる. そこで, これまでの急拡大部におけ る管断面平均ボイド率分布の結果から $C_{0}$ をおよび $V_{\mathrm{Gj}}$ を算出することとする.

図 9 は, 急抎大流路における全体積流束と気相平 均速度の関係を示し, グラフの傾きと切片として $C_{0}$ ならびに $V_{\mathrm{G}}$ を求めることができることから急拡大部 から様々な管断面におけるそれぞれの值を評価した結 果である. $C_{0}$ については, この結果から急拡大部直 後において 7.7 程度を示し, その後下流方向に沿って

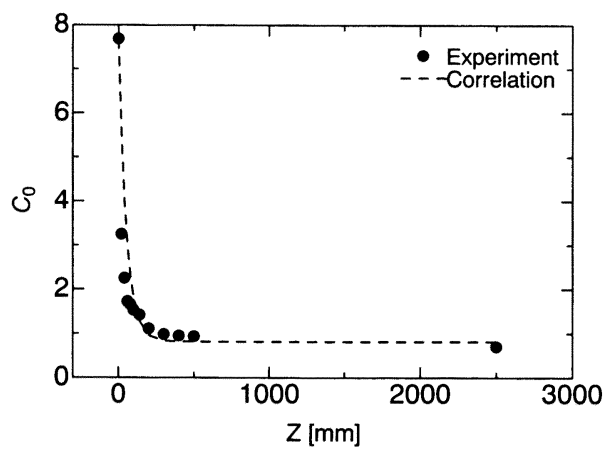

Fig. 10 Correlation of distribution parameter in sudden expansion

徐々に減少しながら急抎大部下流の $2500 \mathrm{~mm}$ 位置で は 0.69 に達する. この結果は, 急拡大部直後での管 中央部に集中するボイド率分布が下流方向へ行くに従 い，下流域ではボイド率分布が変化していることに対 応している. 一方, $V_{\mathrm{Gj}}$ については, 図 9 より急拡大 部下流域では $0.18 \mathrm{~m} / \mathrm{s}$ の值を示し従来の知見と一致す る結果が得られた(2).

図 9 により得られた結果より，急拡大部以降の軸方 向位置における管断面に対する $C_{0}$ の值の变化を図 10 に示す. 本図より, $C_{0}$ は急拡大部からの距離の増加 とともに指数関数的に減少し一定值に達している.こ の結果より得られた $C_{0}$ を概ね次式で近似し, 図 10 中 に破線で併せて示す.

$$
C_{0}=6.993\left[\exp \left(\frac{0.29 z}{h}\right)\right]+0.812
$$

$$
h=\frac{D_{50}-D_{20}}{2}
$$

ここで, $h$ はステップ高さを表し， $D_{20}$ は $20 \mathrm{~mm}$ 管内 径, $D_{50}$ は $50 \mathrm{~mm}$ 管内径である.

このように急挔大流路における詳細なボイド率分布 が明らかにされることで多次元流路におけるボイド率 分布データが提示されるとともに, 式(2)のような分 布定数 $C_{0}$ の変化を構成モデルとして用いることで一 次元モデルに多次元的な効果を組み込むことが可能と なるものと考える.

\section{4. 結 言}

本報では, 多次元流路の典型的な形態である急拡大を 伴う鉛直円管内を上昇する非加熱空気-水系気泡流を対 

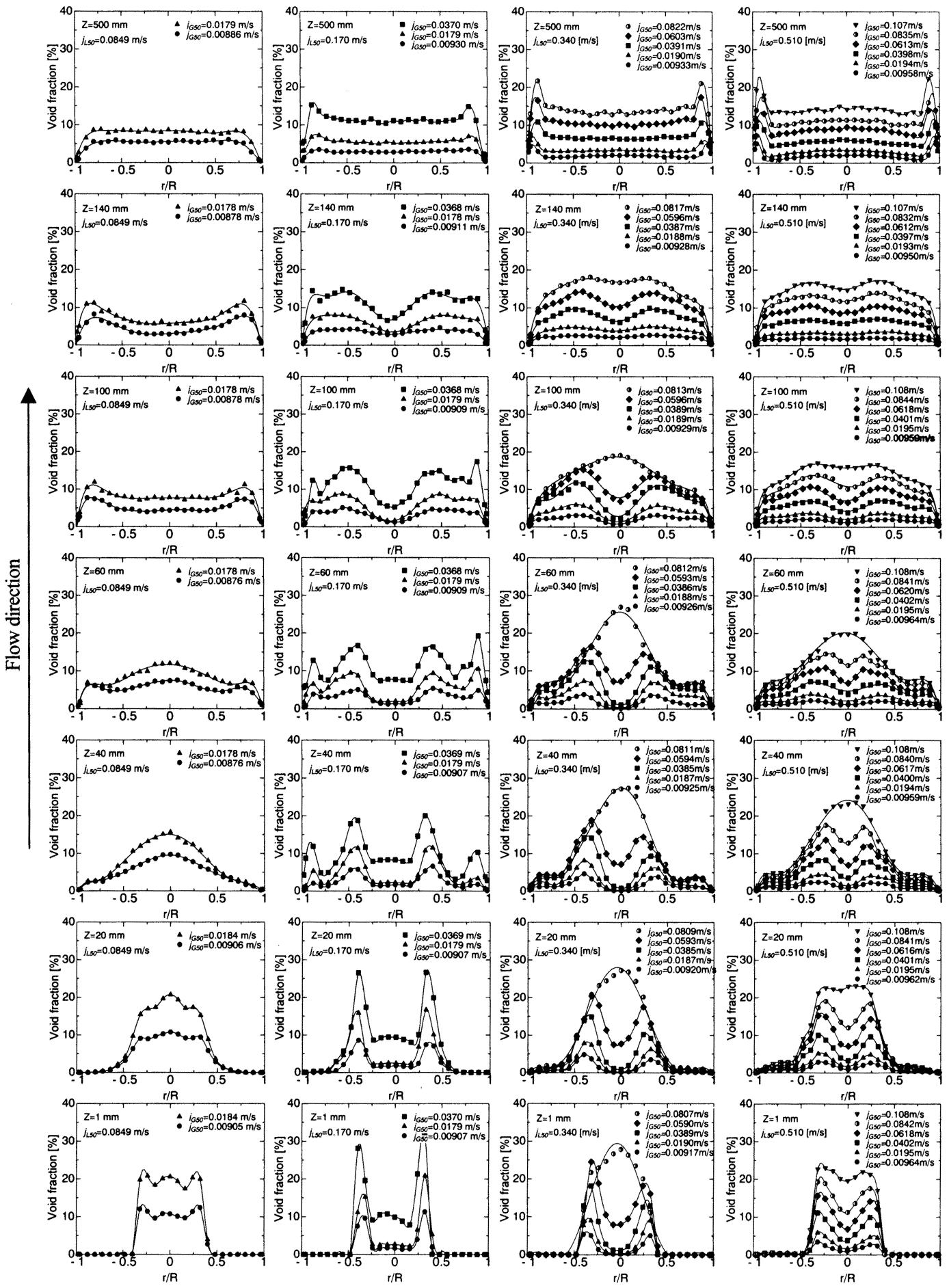
(a) $j_{\mathrm{L} 20}=0.531 \mathrm{~m} / \mathrm{s}$
(b) $j_{\mathrm{L} 20}=1.06 \mathrm{~m} / \mathrm{s}$
$d_{\mathrm{b} 20}=4-5 \mathrm{~mm}$
$d_{\mathrm{b} 20}=3-4 \mathrm{~mm}$

(c) $j_{\mathrm{L} 20}=2.12 \mathrm{~m} / \mathrm{s}$

(d) $j_{\mathrm{L} 20}=3.19 \mathrm{~m} / \mathrm{s}$

$d_{\mathrm{b} 20}=1-2 \mathrm{~mm}$

Appendix 1 Void fraction distribution in the sudden expansion under various bubbly flow conditions 
象として，この流路内の多次元的なボイド率分布を点電 極式ボイドプローブにより測定し, 以下のことを明らか にした.

1. 急拡大流路におけるボイド率分布を様々な気液流 束条件や気泡サイズにわたって詳細に示し, 上流 域から下流域に至るボイド率分布の変化を明らか にすることで多次元的な検証データを示した.

2. 急拡大流路における上記のボイド率測定結果に基 き管断面平均ボイド率を算出し, 急拡大流路にお ける変化を明らかにした.

3. 急拡大流路におけるボイド率分布を一次元モデル により評価するために, ドリフト相関式に基づい た分布定数の検討を行った. これにより急拡大流 路における軸方向ボイド率分布を一次元解析にお いて予測できる可能性を示した.

\section{参考献}

(1) Wallis G. B., One-dimensional two-phase flow, (1969), McGraw-Hill.

(2) Ishii, M., ANL-77-47, (1977).

(3) Liels, D. R., Reed, W. H., J. Computational Physics, Vol.26, (1978), 390-407.

（4）秋元肇・阿部豊 - 大貫晃 - 村尾良夫, JAERIM 91-086, (1991).
(5) Serizawa, A. and Kataoka, I., In: Afgan, N. H. (Ed.), Transient Phenomena in Multiphase Flow, (1988), 179-224, Hemisphere.

(6) Monji, H. and Matsui, G., Proc. $1^{\text {st }}$ Int. Conf. on Multiphase Flow, Tsukuba, Japan, (1991), 449-452.

(7) Liu, T. J., Int. J. Multiphase Flow, vol.19 (1), (1993), 99-113.

(8) Zun, I., Kljenak, I., Moze, S., Int. J. Multiphase Flow, vol.19 (1), (1993), 151-172.

(9) Hibiki, T., Ishii, M. and Xiao, Z., Int. J. Heat Mass Transfer, vol.44, (2001), 1869-1888.

(10) 近藤宏一・吉田憲司・松本忠義 ·大川富雄 片岡勲, 機論, B, (投稿中 : 論文 No. 04-0347)

(11) 佐藤 - 佐田富 - 猿渡, 機論, B, 48-431, (1982), 1416-1419.

(12) Lahey, R. T. Jr., Lopez de Bertodano, M., Jones, O.C., Nucl. Eng. Des., vol.141, (1993), 177-201.

(13) 賞雅寛而・近藤宏一, 機論, B, 61-587, (1995), 2372-2378.

(14) Aloui, F., Doubliez, L., Legrand, J. and Souhar, M., Experimental Thermal and Fluid Sci., vol.19 (2) (1999), 118. 